\title{
UMBDARA
}

Indonesian Journal of Anthropology

Volume 5 (2) Desember 2020 || eISSN 2528-1569

DOI : 10.24198/umbara.v5i2.29962

\section{Kuasa Tubuh dan Perlawanan: Anti Politisasi dan Komodifikasi Tubuh Perempuan dalam Ruang Virtual}

\author{
Tari Purwanti \\ Departemen Antropologi, Fakultas Ilmu Budaya, Universitas Gadjah Mada \\ taripurwanti01@gmail.com
}

\begin{abstract}
This study discusses the discourse of "self love" as a form of women's resistance against the politicization of their body in the virtual space, and how biopolitic and propaganda made by Indonesian government to counter pornographic activities in the virtual space. This study applied qualitative descriptive method. Data were collected through observations and interviews with social media accounts owner on their actualization of self-love. This study finds that the practice of anti-politicization against female body often misinterpreted as the practice of self-commodification. This study also suggest that objectification against women's body is not always caused by men, but also by women. On the other hand, the state also has power over the body of its citizens has full control over all of their actions in social media. The state ward off discourses of self-love that lead to self-commodification through various policies and laws.
\end{abstract}

Keywords: self love, biopolitics, self commodification, body power, counter-attack country

\begin{abstract}
Abstrak
Penelitian ini bertujuan untuk menggambarkan wacana cinta diri atau "self love" sebagai bentuk perlawanan oleh perempuan terhadap politisasi tubuh di ruang virtual, dan bagaimana biopolitik dan propaganda yang dilakukan oleh Indonesia untuk menanggapi aktivitas yang dianggap berbau pornografi di ruang virtual. Penelitian ini bersifat deksriptif kualitatif. Data dikumpulkan dari observasi dan wawancara terhadap sejumlah informan; dan juga mencermati akun media sosial. Fokus pengamatan pada aktualisasi wacana cinta diri (selflove) sebagai bahan analisis tentang praktik antipolitisasi tubuh atau biopolitik yang digaungkan di media sosial sebagai ruang virtual yang menjadi wadah gerakan self love sebagai bentuk kuasa atas tubuhnya. Hasil penelitian ini menunjukkan bahwa praktik anti politisasi atas tubuh perempuan seringkali disalahpahami sebagai praktik komodifikasi tubuh sehingga membuat perempuan menjadikan tubuhnya sebagai komoditi yang menghasilkan keuntungan pribadi yang menempatkan dirinya sebagai subjek sekaligus objek. Objektivikasi tidak selalu diakibatkan oleh peran laki-laki, tetapi juga oleh perempuan sendiri. Di sisi lain, negara sebagai pemilik kuasa atas tubuh warga negaranya menciptakan berbagai kebijakan dan hukum dalam bentuk undang-undang untuk mengontrol secara penuh segala tindakan yang terjadi di media sosial dan untuk meng-counter wacana self love yang berujung pada komodifikasi pribadi
\end{abstract}


(self commodification) ini.

Kata kunci: self love, biopolitik, self commodification, kuasa tubuh, counter-attack negara

\section{Pendahuluan}

Kecanggihan teknologi yang mendukung keterbukaan informasi di dunia virtual berdampak pada masuknya ideologi-ideologi atau pemahaman yang menyimpang. Namun, ideologi-ideologi tersebut kemudian justru digiring menjadi pemahaman yang dianggap lumrah atau biasa terjadi, salah satunya berkaitan dengan tubuh perempuan. Tubuh memiliki berbagai macam definisi, yakni tubuh secara biologis dan tubuh secara sosial, termasuk di dalamnya definisi tubuh di ranah politik ekonomi dan ideologi tentang tubuh. Mengutip pernyataan Aquarini Priyatna bahwa "tubuh merupakan ranah politis dan ideologis...yang menjalani pemaknaan karena proses budaya", sehingga segala hal tentang tubuh tidak terlepas dari situasi politik yang melatarbelakanginya. Tubuh perempuan menjadi komoditas politik dan dikomersialisasikan oleh kapitalisme, tetapi tidak boleh dikomersialkan oleh pemiliknya sendiri ${ }^{2}$. Tubuh perempuan menjadi cerminan makna moralitas dan komoditas, dihujani oleh sistem hukum, politik dan ekonomi dan agama, serta dengan mudah dikriminalisasi ketika terjadi penyimpangan yang dilakukan oleh tubuh. Namun, di dunia virtual, terdapat fenomena perempuan-perempuan yang dengan kesadarannya memperlihatkan bagian-bagian tubuhnya dengan wacana "self love" meski dihantui oleh UU ITE, terutama yang berkaitan dengan pornografi. Ide tentang normalisasi dan idealisasi tubuh ini dianggap sebagai perlawanan atas kekuasaan yang memodifikasi tubuh secara politis.

Pembahasan mengenai politisasi dan komer- sialisasi tubuh perempuan pernah ditulis oleh beberapa peneliti, di antaranya adalah tulisan Priyatna mengenai "Becoming White: Representasi Ras, Kelas, Feminitas dan Globalitas dalam iklan sabun" yang memperlihatkan bagaimana kapitalisme mengubah citra tubuh perempuan secara politis dan ekonomis. Kedua, tulisan tentang politisasi perempuan dalam kaitannya dengan media sosial dan hukum (Marwick, 2015; Middleweek, 2020). Ketiga, tulisan-tulisan kuasa tubuh atas perempuan, seksualitas dan gender (Atkinson, 2020; Dzulkarnain, 2015; Keller, 2020; Naezer, 2020). Keempat, tulisan-tulisan yang berfokus pada kapitalisasi tubuh perempuan dalam perspektif hukum dan agama (Shinta, 2017; Susilo dan Kodir, 2016). Tulisan-tulisan tersebut telah banyak mengulas tubuh, terutama tubuh perempuan, seolah berada di dalam jaring laba-laba yang setiap sambungannya mengaitkan persoalan-persoalan sosial, politik, ekonomi, dan agama. Namun, dari semua tulisan yang ada, belum ada yang membahas perlawanan perempuan dalam ruang virtual dan upaya negara menghadapi fenomena tersebut.

Kajian Foucault (1995) terhadap praktik politik penaklukan tubuh memperlihatkan bahwa praktik ini telah terjadi sejak abad ke-17 dan 18 , ketika sistem yang dominan melakukan penaklukan atas tubuh. Di dalam pandangan Nietzche, tubuh bukan sekadar badan biologis yang dapat dimanfaatkan melalui banyak cara melainkan gambaran hasrat dalam tubuh yang dapat diubah melalui interpretasi budaya, dan setiap aspeknya dapat dimodifikasi melalui teknik-teknik yang sesuai. Oleh karena itu,

\footnotetext{
${ }^{1}$ Pendapat ini dikemukakan oleh Aquarini Priyatna, dalam acara Unboxing Tari: Politik, Tubuh dan Ruang yang digelar Dewan Kesenian Jakarta di Taman Ismail Marzuki, Jakarta, Rabu (24/04), Harahap (2011), https://www. gatra.com/detail/news/412232//melempar-seperti-perempuan-renungan-aquarini-tentang-politik-tubuh.

${ }^{2}$ Dikutip dari podcast Anna Marsiana dalam judul "Polemik Postingan Tara Basro dan Politisasi Tubuh Perempuan” dalam https://oikoumene.id/polemik-postingan-tara-basro-dan-politisasi-tubuh-perempuan/
} 
dapat dikatakan bahwa tubuh adalah entitas yang lunak, dapat ditundukkan dan ditempa sedemikian rupa.

Praktik rasisme yang terjadi di berbagai belahan dunia menunjukkan politik tubuh yang bekerja sebagai dasar dominasi dan intersubjektivitas terhadap tubuh. Sejalan dengan yang dikemukakan oleh Coleman (1986), bahwa kemampuan untuk mengendalikan tubuh adalah implikasi dari hubungan kekuasaan atas pihak-pihak lain yang memiliki wewenang untuk itu, sebagaimana negara yang menjadikan tubuh sebagai alat objektivikasi untuk mengontrol dan mengendalikan masyarakat, terutama perempuan, termasuk di ruang virtual. Penelitian ini bertujuan melengkapi kekurangan studi yang ada untuk menggambarkan secara utuh mengenai wacana cinta diri atau "self love" yang menjadi sebuah bentuk perlawanan oleh perempuan terhadap politisasi tubuh di ruang virtual. Penelitian ini juga bertujuan menggambarkan biopolitik dan propaganda yang dilakukan oleh negara Indonesia untuk meng-counter aktivitas yang dianggap berbau pornografi di ruang virtual.

Tubuh secara struktur adalah milik individu yang tidak dapat berpindah hak milik dan otoritasnya. Namun, negara memiliki kuasa untuk mengendalikan dan mengontrol tubuh sebagai implikasi dari otoritas dan dominasi sistem yang ada untuk mematuhkan dan menundukkan tubuh. Misal, seperti mengatur tubuh masyarakat dalam hal berpakaian, penggunaan alat kontrasepsi/KB, pengendalian kehamilan, seksualitas, pernikahan dan lain sebagainya. Itu semua telah dipatuhkan oleh beragam peraturan, norma, ataupun kebijakan-kebijakan yang dibuat oleh negara. Maka dari itu, kekuasan dianggap sebagai suatu tindakan yang membelenggu tubuh. Ruang-ruang untuk melancarkan dan mempropagandakan praktik biopolitik tidak hanya terjadi di ruang nyata, namun juga di ruang virtual. Sementara itu, aktivitas propaganda "self love" di ruang virtual bagaikan pedang bermata dua, di satu sisi ia menyuarakan perlawanan pemi- lik tubuh terhadap politisasi pada tubuh mereka yang dilakukan oleh negara, tetapi di sisi lain hal itu justru disalahpahami sebagai wujud tindakan yang berlawanan dengan hukum negara.

\section{Kajian Pustaka}

\section{Tubuh Perempuan}

Beauvoir dalam Barker (2005) mengatakan bahwa tubuh bukanlah sebuah benda, tetapi suatu situasi dan cengkeraman kita terhadap dunia sosial dan sketsa kita terhadap dunia sosial. Bagian tubuh dan atribut tubuh bersifat sosial, yakni berkaitan dengan ruang tempat ia berada dan bekerja, sedangkan dalam aspek sosial, tubuh menjadi unsur pokok identitas personal (Raditya, 2014). Sejalan dengan itu, Saptandari (2013) mengemukakan bahwa kajian terhadap tubuh perempuan melingkupi dua kajian utama, yaitu pertama, bahwa tubuh berada di dalam ranah seksualitas, tetapi kemudian mengalami paradoks dan ironi. Paradoks dan ironi ini memperlihatkan bahwa tubuh perempuan selalu berbenturan dengan norma dan nilai sosial yang diterapkan di dalam lingkungan masyarakat. Hal ini mengakibatkan perempuan selalu terikat dalam beragam aturan yang melingkupi tubuhnya, misalnya dalam konteks berpakaian, berlaku pengendalian sosial melalui citra "tubuh ideal". Kedua, pemaknaan terhadap perempuan, baik di ranah publik ataupun ranah privat menempatkan perempuan di dalam posisi yang subordinat, posisinya selalu berada di bawah dominasi kekuasaan laki-laki (patriarki). Hal ini mengakibatkan kerentanan perempuan dalam kehidupan sosial baik secara fisik, reproduksi, dan eksistensi mereka.

Posisi perempuan dikonstruksikan secara sosial sebagai perlawanan posisi (oposisi biner) dari laki-laki. Laki-laki dibangun dengan makna-makna atas (up), kanan (right), tinggi (high), kekuatan (power), dan kekuatan (strength). Makna-makna ini beroposisi dengan perempuan yang selalu ditempatkan pada posisi yang sebaliknya, yakni bawah (down), alam (nature), dan kelemahan (weakness) (Moore 
dalam Saptandari, 2013). Pemaknaan ini menempatkan perempuan pada posisi yang tersubordinasi. Hal ini terbentuk karena sistem nilai, kepercayaan, pendidikan, tingkah laku yang berangkat dari kerangka kerja patriarki, yang melakukan justifikasi terhadap hubungan subordinatif yang memperlihatkan penindasan terjadap kaum perempuan.

\section{Kuasa Tubuh}

Pembahasan mengenai kuasa telah sering dibicarakan oleh para filsuf kontemporer, salah satunya yaitu Michel Foucault. Foucault membahas kuasa dalam lingkup mikro, dan menggambarkannya sebagai relasi yang beragam dan tersebar, tetapi memiliki cakupan bahasan yang strategis. Menurut Foucault, kuasa tidak dimiliki, tapi dipraktikkan. Kuasa bukan merupakan hak milik melainkan sebuah strategi, sehingga strategi kuasa di mana pun memiliki struktur, aturan, sistem regulasi dan sebagainya. Foucault juga menggambarkan bahwa kuasa tidak hanya bersifat destruktif, melainkan juga produktif dan konstruktif, sehingga kuasa dapat memiliki arti yang baik.

Foucault juga membahas kuasa dari segi pendisiplinan tubuh. Di dalam bukunya yang berjudul "Discipline and Punishment", Foucault menggambarkan kuasa terhadap tubuh sebagai kamera panopticon, yakni sebuah bentuk bangunan yang digunakan di institusi ataupun penjara-penjara di Inggris, yang memiliki sistem kontrol yang penuh untuk dapat terus mengendalikan apa yang ada di dalamnya agar disiplin. Disiplin tubuh menurut Foucault adalah sebuah teknologi kuasa untuk menundukkan dan mendisiplinkan tubuh agar patuh dan berguna sebagai anatomi politis yang baru. Foucault dalam karyanya membicarakan bahwa tubuh merupakan wilayah di mana relasi kuasa bekerja di atasnya dan beragam aturan kuasa selalu melingkupinya. Relasi kuasa atas tubuh seringkali bersifat memaksa, membentuk, menanamkan dan menguasai tubuh. Foucault menyebut hal tersebut sebagai perwujudan disciplinary power (Hardiyanto, 1997).
Praktik pendisiplinan tubuh ini dapat dijumpai di berbagai institusi, melalui seperangkat aturannya, seperti kantor-kantor pemerintahan, rumah sakit, penjara, lembaga pendidikan, pondok pesantren, akademi kemiliteran dan lain sebagainya. Upaya untuk membentuk perilaku tubuh yang patuh dan dapat "ditundukkan" melalui mekanisme pendisiplinan tubuh terhadap masyarakat modern terdiri atas tiga tindakan. Pertama, melalui "pengamatan atau pengawasan hierarkis". Di dalam hal ini, Foucault mencontohkannya dengan model "panoptikon" di mana seorang pengawas dapat mengamati gerak-gerik orang lain melalui menara pengawas tanpa diketahui oleh orang yang sedang diamati. Kedua, melalui normalisasi, penciptaan norma-norma dan pembiasaan, yakni dengan memanfaatkan instrumen kekuasaan pendisiplinan sesuai standar atau norma tertentu. Ketiga, adalah pengujian yang didasarkan pada penggabungan penilaian model pengamatan hierarkis dan normalisasi. Tubuh membuat manusia dapat disentuh dan dilihat, karena tubuh merupakan sebuah realitas dasar eksistensi manusia. Gagasan, hasrat, emosi, harapan, dan kegelisahan berada pada titik pijakan yang ada pada tubuh, sehingga Foucault menganggap bahwa kekuasan merupakan bagian utama yang diperankan oleh tubuh. Tubuh merupakan sasaran kekuasaan yang dapat direkayasa, dilatih, dan disiplinkan, sehingga tubuh memiliki nilai-nilai kepatuhan yang menjadi tujuan utama dari kekuasaan.

\section{Politisasi Tubuh}

Pembahasan mengenai the body politics pernah ditulis oleh Marcuse (1995, edisi kedua, 1996) dalam bukunya yang berjudul Eros and Civilization. Namun, buku ini menuai beragam komentar pro-kontra karena dianggap memperlihatkan gagasannya yang utopis. Marcuse berpendapat bahwa "industrialisasi menuntut penghematan erotis". Pandangan ini dibantah oleh Michael Foucault dalam The History of Sexuality. Foucault merombak pemikiran Marcuse yang disebutnya "hipotesis represif. Menurutnya, meskipun institusi-institusi modern telah banyak 
menawarkan manfaat, tetapi tidak dapat dipungkiri bahwasannya institusi-institusi tersebut telah melakukan pemaksaan terhadap tubuh, yaitu dengan melakukan penekanan terhadap seksualitas. Peradaban modern menurut Foucault adalah peradaban yang menundukkan manusia untuk mencapai kedisiplinan dengan tujuan menciptakan kontrol terhadap perilaku manusia.

Foucault memperkenalkan spesifikasi detail yang sangat dibutuhkan ke dalam analisis Marcusean yang dianggap sangat abstrak. Tubuh, yang menurut Marcuse tunduk pada penindasan surplus "prinsip kerja" diuraikan dengan sangat jelas: tidak hanya di tempat kerja dan bermain, namun juga di penjara, rumah sakit, rumah sakit jiwa, dan sekolah. Dia memusatkan perhatian kita pada tubuh manusia sebagai situs penting dari investasi politik yang kuat, dan lebih fokus pada perincian. Foucault merinci pertanyaan teori sosial dan menargetkan secara langsung jenis tubuh yang dibutuhkan oleh teknologi yang terorganisir secara kapitalis. Tubuh jenis ekonomi ini membentuk, memproduksi, menginformasikan, memberi hadiah, menghukum, mengontrol, menggunakan, dan menghancurkan. Foucault memandang kehidupan modern sebagai kehidupan yang erat hubungannya dengan "kuasa disiplin" (disciplinary power), yaitu kuasa yang berkelindan dengan institusi-institusi seperti penjara, perusahaan-perusahaan, institusi militer, rumah sakit jiwa, rumah sakit, dan sekolah.

Kontrol yang sangat kuat terhadap tubuh melahirkan kuasa dan budaya-budaya disiplin (misal, patriarki dan kyarki) yang dikendalikan oleh otoritas yang tinggi. Hal ini muncul karena pandangan bahwa kedisiplinan adalah hal yang sangat penting dibandingkan hal lainnnya. Disciplinary power bertujuan untuk memproduksi tubuh-tubuh yang jinak (docile bodies), patuh, dan teratur, sehingga setiap perilakunya dapat dikontrol dan diregulasi, tanpa mempertimbangkan nuraninya. Pada peradaban modern, seksualitas dan kekuasaan saling berkaitan dalam beragam pola yang berbeda-beda. Foucault menyebut hal itu dengan istilah "psikiatri kesenangan", yaitu pelarangan terhadap praktik seksualitas erotis yang dianggap menyimpang, tidak normal, dan perlu perawatan (Giddens, 1985). Psikiatri kesenangan ini berkaitan dengan kategorisasi perilaku seksual yang abnormal atau tidak wajar dan diungkapkan kepada publik sebagai klasifikasi perilaku individu, identitas diri, dan kepribadian.

Kekuasaan kedisiplinan yang kuat melalui beragam peraturan yang baku menciptakan sebuah kontrol pendisiplinan tubuh yang ampuh dalam segala elemen kehidupan institusi. Kuasa disiplin ini menciptakan tubuh jinak yang dapat dikontrol, dikuasai, ditundukkan, dipatuhkan sesuai dengan pihak yang memiliki otoritas/kekuasaan (dalam hal ini kaum patriarki dan kyarki). Sebagaimana yang digambarkan oleh Foucault bahwa ideologi patriarki diawali dari terkikisnya peradaban tradisional dan berubah ke peradaban modern, sehingga wacana penegasan terhadap maskulinitas dan feminitas melahirkan praktik disiplin dan diskursif.

\section{Feminisme di Ruang Virtual}

Media sosial sebagai ruang virtual memberikan berbagai macam fasilitas yang dapat menghubungkan para penggunanya dari seluruh dunia. Beragam fasilitas atau fitur seperti perpesanan, panggilan video, dan pertukaran foto melalui pesan pribadi, status, cuitan, ataupun jejak digital lainnya memungkinkan terjadinya keterbukaan informasi yang tidak dapat dihindarkan. Badai informasi ini di satu sisi menjadi sebuah sisi negatif dari media sosial, sebagaimana yang disampaikan oleh Nagarajan (2016): "What does it mean when the primary spaces for so many public and private interactions, including activism, are owned by corporations from one part of the world, run by mainly white men?" Di sisi lain, Ott (2018) menyatakan bahwa pengguna media sosial dalam budaya partisipatif membawa dan menciptakan hierarki di ruang terbuka di internet.

Di samping itu, ruang virtual juga menghadirkan sebuah gerakan baru yang dikenal 
dengan feminisme daring (online feminism). Feminisme daring atau online feminism ini merupakan bentuk baru dari kajian feminisme sebagai akibat dari kemajuan teknologi dan invasi sosial media dewasa ini. Feminisme di dalam sosial media sebagaimana yang dikutip dari Ott (2018):

"...is an exploration of how communities form and interact in social media spaces as well as if values expressed via these participatory cultures align or misalign with feminist ethical criteria. Digital social media invite participation based on the values of openness, collaboration, and networking, which in theory align with feminist values such as access, cooperation, and inclusion."

Feminisme daring atau online feminism adalah jaringan aktivisme yang bersifat inklusif dan interseksional. Association for Progressive Communication (APC) mengungkapkan bahwa feminis internet bekerja untuk memberdayakan lebih banyak perempuan dan orang-orang yang memiliki keunikan (queer persons) dalam segala bentuk keragaman untuk secara penuh menikmati hak setiap individu, terlibat dalam kesenangan dan permainan, dan membongkar patriarki (Association of Progressive Communication, 2016). Perempuan dari seluruh penjuru dunia disatukan melaui internet dalam sosial media dan berperan dalam gerakan sosial baru berbasis teknologi dan pemberdayaan perempuan.

Gerakan feminisme daring atau feminis internet menurut Nagarajan (2016) muncul karena gerakan ini melibatkan wanita dari seluruh dunia; dan dikatakan sebagai feminis internet karena merupakan gerakan yang menggabungkan kritik canggih terhadap tekno-kapitalisme neoliberal dan pengawasan global. Gerakan ini menemukan adanya pelecehan online terhadap wanita dan anak perempuan, dan menempatkannya dalam konteks kekerasan yang lebih besar, sehingga dapat menghadirkan masalah lain yang mempengaruhi wanita secara global.

\section{Cinta Diri (Self Love)}

Wacana cinta diri atau self love di Indonesia telah muncul sejak lama, namun baru digaungkan secara masif sejak postingan Tara Basro yang memperlihatkan foto dirinya dalam keadaan terbuka dan memeluk dirinya sendiri. Alih-alih memposting foto yang menampakkan sisi yang sempurna, dalam foto tersebut yang diunggahnya ke media sosial Twitter dan Instagram, Tara Basro secara tidak langsung menyinggung wacana "self love" di akun media sosialnya sebagai bentuk penyemangat dan ajakan kepada perempuan untuk mencintai diri sendiri dengan ketidaksempurnaannya. Ia menulis:

"Dari dulu yang selalu gue denger dari orang adalah hal jelek tentang tubuh mereka, akhirnya gue pun terbiasa ngelakuin hal yang sama mengkritik dan menjelek-jelekkan. Andaikan kita lebih terbiasa untuk melihat hal yang baik dan positif, bersyukur dengan apa yang kita miliki dan make the best out of it daripada fokus dengan apa yang tidak kita miliki. Setelah perjalanan yang panjang gue bisa bilang kalau gue cinta sama tubuh gue dan gue bangga akan itu. Let yourself bloom ${ }^{3}$." (dalam postingan Instagram@tarabasro, 3 Maret 2020)

Postingan tersebut menimbulkan banyak kritik yang membagi netizen ke dalam dua kubu, yakni kubu yang pro dan kontra terhadap keterbukaan di ruang virtual. Kubu yang pro terhadap keterbukaan di ruang media sosial menilai bahwa apa yang dilakukan Tara Basro adalah untuk menerima segala kekurangan yang dimiliki tubuh -dalam hal ini perempuan- dan merasa cukup di tengah arus konsumerisme dan tekanan untuk tampil cantik yang seringkali membuat perempuan enggan menerima kekurangan dirinya dan melakukan segala cara untuk memperindah tubuhnya. Di sisi lain, kubu kontra menilai bahwa apa yang dilakukan Tara Basro adalah hal yang kontroversial dan berpotensi menyalahi Pasal 27

\footnotetext{
${ }^{3}$ Postingan tersebut dapat dilihat di link berikut: https://www.instagram.com/p/B9RiWERHeup/
} 
ayat (1) UU Nomor 11 tahun 2008 Tentang Informasi dan Transaksi Elektronik (UU ITE). Namun, tidak lama setelah postingan tersebut viral, Ia kemudian mengarsipkan foto tersebut untuk menghindari kegaduhan; tapi tidak lama kemudian ia kembali memunculkan unggahan itu.

Wacana self love dalam kajian psikologi feminisme tidak dapat dipisahkan dari kajian psikoanalis feminis. Spielrein (1913) dalam Lianawati (2020) menulis tentang empati sebagai bentuk kekuatan psikis perempuan yang membedakannya dengan laki-laki. Di dalam hal ini terdapat perbedaan cara-cara yang ditempuh perempuan dan laki-laki dalam usaha untuk menerima dirinya sendiri secara utuh berdasarkan pada lingkungan sosial budaya.

Self love menurut Thompson (2016) adalah konsep yang merujuk pada cara individu mencintai perjalanan pribadinya untuk menemukan dirinya sendiri dengan menerima segala perubahan dan masa lalu. Menurut Khoshaba (2012), self love merupakan kondisi ketika individu dapat memvalidasi dirinya sendiri dengan menghargai dan mengapresiasi diri ketika dapat menentukan sebuah keputusan. Oleh karena itu, konsep cinta diri atau self love adalah pondasi yang memungkinkan manusia menjadi individu yang tegas, dapat menentukan batasan untuk diri sendiri dan orang lain, menerima segala kekurangan yang ada dalam diri dan berfokus pada harga diri, namun tidak serta merta menjadi individu yang angkuh.

\section{Praktik Politisasi dan Perlawanan di Ru- ang Virtual}

Brook (2012) dalam bukunya yang berjudul Resisting the Virtual Life mengatakan bahwa:

\section{"Manusia telah tiba di alam virtualitas, ketika teknologi digital mengambil alih kebiasaan interaksi dengan bertatap mukamenjadiinteraksididuniamaya".}

Di dalam karya tersebut, Brook memperlihatkan munculnya perubahan kehidupan sosial budaya manusia dari yang bersifat realis menjadi digi- tal/virtual karena adanya pengaruh kemajuan teknologi informasi, globalisasi, dan internet. Berbagai fasilitas yang pada awalnya hanya ditemukan di dunia nyata kini dapat diakses melalui internet, seperti belanja online, sensus penduduk, bahkan klinik kesehatan virtual. Ketika berbicara mengenai internet dan ruang virtual, maka dengan otomatis pembahasan mengenai media sosial turut serta di belakangnya. Saat ini media sosial telah menjamur dengan berbagai platform yang selain digunakan untuk bersosialisasi dengan banyak orang, juga digunakan sebagai tempat berekspresi dengan bebas, bahkan menjadi ruang-ruang untuk menyampaikan aspirasi dan kritik terhadap pemerintah, sistem dunia, dan sebagainya.

Era media sosial telah mengubah hampir seluruh aspek kehidupan manusia, tidak hanya dalam hal memudahkan komunikasi, tetapi mengubah cara manusia berpikir dan mengkonstruksi ide serta wacana (Alyusi, 2017). Media sosial seringkali digunakan sebagai media dalam berpolitik. Media sosial menjadi sarana perlawanan masyarakat kepada pemerintah, dan juga digunakan oleh pemerintah merespon berbagai isu yang terjadi untuk mengembalikan kepercayaan masyarakat. Internet menciptakan jaringan komunikasi yang memainkan peran dalam peredaran berita, dan media sosial memiliki kekuatan untuk mengubah tidak hanya pesannya, tetapi juga dinamika politik, nilai dan dinamika konflik politik yang terjadi (Singer, 2018).

Media sosial saat ini telah menjadi ruang untuk terjadinya peran partisipatif yang mempertemukan masyarakat dengan pemerintah, dengan ide mengenai new media populism yang memungkinkan publik untuk memiliki peran yang terlibat dan aktif dalam wacana politik. New media, termasuk di dalamnya platform sosial media seperti Facebook, Twitter, VK dan sebagainya dapat meningkatkan akses publik terhadap informasi politik (Owen, 2018). Di dalam tulisannya, Howard Rheingold menyampaikan:

"The political significance of computer mediated communication lies in its ca- 
pacity to challenge the existing political hierarchy's monopoly on powerful communication media, and perhaprs thus revitalize citizen-based democracy." (Rheingold, 1993 dalam Mark, 2013).

Praktik regulasi pemerintah terhadap media sosial semakin berkembang karena masalah ekonomi, monopoli platform, masalah privasi, sensor, netralitas jaringan, dan penyimpangan informasi. Pembahasan peraturan ini menjadi rumit karena masalah yang terdapat di platform-platform media sosial sebagai penyedia konten berada pada pengawasan pemerintah yang mengatur platform tersebut (Mark, 2013). Pemerintah menciptakan berbagai undangundang yang di dalamnya mencakup kebijakan di ruang virtual yang diatur dengan UU ITE yang disahkan DPR pada tahun 2008 untuk menjaga lingkungan bersosial media. Namun, seringkali kebijakan ini justru tebang pilih terhadap pelanggarnya.

\section{Metode Penelitian}

Penelitian ini bersifat deksriptif kualitatif untuk mencermati akun media sosial yang berfokus pada aktualisasi wacana self love dan self commodification. Penelitian ini menganalisis interaksi yang terjadi dan muatan yang terkandung dalam wacana self love, dan serta bagaimana self commodification terjadi di tengah digaungkannya wacana self love ini. Teknik pengumpulan data pada penelitian ini melalui observasi dan wawancara terhadap sejumlah informan yang mengunggah fotofoto bermuatan ketelanjangan dengan wacana self love. Wacancara dilakukan melalui Direct Message (DM) pada platform media sosial Twitter dan Instagram secara terstruktur. Data dianalisis dengan menggunakan metode content analysis dengan terlebih dikelompokkan berdasarkan dua karakteristik: 1) unggahan yang menggaungkan propaganda self love, dan 2) unggahan yang menggambarkan pemahaman yang salah tentang propaganda tersebut.

\section{Hasil dan Pembahasan}

\section{Antipolitisasi, Komodifikasi Tubuh Sendi- ri (self-commodification), dan Perlawanan Praktik Politisasi Tubuh}

Pencarian data mengenai self love pada tanggal 9 Mei 2020, menghasilkan 950 cuitan di media sosial Twitter, dan 41.460.138 unggahan di Instagram dengan tagar \#selflove. Namun, karena keterbatasan akses, cukup sulit untuk memisahkan persentase postingan self love yang berasal dari Indonesia. Dari sekian banyak unggahan, dikelompokkan dalam kategori foto-foto yang kontroversial (dalam hal ini menunjukkan ketelanjangan) dengan menambahkan wacana "selflove", khususnya perempuan Indonesia. Setelah itu, beberapa akun yang memposting foto-foto dengan tagar tersebut ditelusuri lebih lanjut dan pemiliki akun dikontak secara personal untuk diwawancara.

Rangkuman jawaban informan tampak dalam tabel berikut:

\begin{tabular}{lll}
\hline \multicolumn{1}{c}{ Pertanyaan } & \multicolumn{1}{c}{ Jawaban } & Makna \\
\hline Alasan dan moti- & @melanatedxxx: "aku rasa tubuh kita memiliki nilai yang & Penerimaan diri \\
vasi mengunggah & tidak harus selalu diterima oleh orang lain. Ketika melaku- \\
foto- foto kontro- & kan ini kamu percaya bahwa kamu tidak lagi membutuhkan \\
versial dan bertagar & penerimaan dari orang lain dan hanya perlu dirimu sendiri \\
self love & untuk menerima. Mene- rima itu ga cuma soal tubuh aja, tapi \\
& juga dengan perasaan-perasaan di dalamnya." & \\
& @Lilsunnyxxx: "Mencintai diri sendiri adalah bentuk cinta & Kuasa atas \\
& yang sesungguhnya. Ketika kamu mencintai diri sendiri, kamu tubuh \\
& memiliki kuasa penuh atas tubuhmu. Dan tidak ada seorangpun & \\
& yang mengendalikan kamu."
\end{tabular}


@chloexxx: "Dulu aku memiliki kepercayaan diri yang Penerimaan diri rendah. Stretchmark, jerawat, rambut rontok, gendut, kulit yang gelap. Setelah lama bergelut di dunia skin care, ke klinik kecantikan sana sini dan habis puluhan juta (hampir seratus juta sih sampe tahun lalu), akhirnya aku menyadari ini gak akan ada habisnya. Lebih baik aku menerima diriku sendiri dan inilah aku sekarang. Dengan berbagai kekurangan mencoba mencintai diri sendiri dan lebih bahagia."

@yoursugarbabyxxx: "Ruang virtual kan ruang bebas yah.

Kebebasan

Menurutku sih, meskipun ada UU ITE, asalkan kita mampu untuk mempertimbangkan resiko, ya sah-sah aja kan posting-posting foto-foto seksi dengan tagar self love?"

@ sedvctipxxx: "Bagiku, posting foto seksi sih bukan cuma sebagai bentuk kecintaan kepada diri sendiri ya, tapi lebih dari itu, ini tu perlawanan kepada sistem yang ada. Katanya kita dilindungi hukum, dengan berbagai undang-undang yang menaungi kita, tapi kok kita malah terpenjara? Jadi menurutku ini sebagai bentuk kebebasan berekspresi. Karena di mana lagi kita bisa menunjukkan eksistensi, selain di media sosial? Followers-ku banyak kok yang anggota polisi. Hahaha" @guiltywhalesxxx: "Tubuhku ya milikku. Ga ada yang berhak mengaturku untuk melakukan ini dan itu. Aku melakukan apa Kuasa penuh yang aku suka. Bebas danmerdeka. Terserah orang lainmenilaiku nakal, lont*, atau apapun. Aku bebas dan menjadi diriku sendiri dan gaberada dibawah aturan orang lain. Pokoknya aku cinta diriku!" @awcabyyxxx: "Kadang gabut dan jenuh aja sih liat timeline isinya politik mulu, bencana mulu, agama mulu. Bosen. Perlawanan dan kebebasan berekspresi Sesekali pengen dong liat yang seger-seger? Jadi aku posting itu buat diliat mutualku biar mereka ga jenuh juga kayak aku. Sebenernya sih khawatir ada ya, apalagi kalo dikaitkan sama UU ITE. Tapi aku merasa tubuh kita berhak kita apresiasi dengan tinggi. Bahkan penilaian dari orang lain tentang tubuh kita juga ga masalah sih, asal kita enjoy. Yang penting ga usah terlalu dipikirkan kalo yang jelek-jelek."

Tabel 1. Praktik-praktik anti-politisasi di media sosial memperlihatkan perlawanan atas politisasi tubuh

Berdasarkan tabel 1, alasan dan motivasi pemilik akun untuk mengunggah foto-foto kontroversial yaitu mengekspresikan penerimaan diri mereka secara utuh atas tubuh mereka, penegasan kuasa penuh atas tubuh, simbol kebebasan dan sikap menghadapi kejenuhan, dan menunjukkan bahwa tubuh secara pribadi tidak ingin ditundukkan, dilemahkan, dan dikendalikan termasuk oleh pemerintah yang membuat berbagai kebijakan untuk mematuhkan tubuh. Keberadaan UU ITE yang mengatur regulasi penggunaan media sosial, terutama yang berkaitan dengan pornografi nampaknya tidak menjadi hambatan kebebasan berekspresi para pemilik akun di ruang media sosial.

Selain mengunggah beberapa foto yang kontroversial, beberapa pemilik akun juga memperjual-belikan foto-foto atau video pribadi dengan istilah "jual konten". Konten yang dimaksud adalah foto-foto serta video pribadi yang seringkali tanpa sensor, yang mereka perjual-belikan untuk mendapatkan keuntungan pribadi melalui komodifikasi diri (self com- 
modification). Data yang diperoleh mengenai komodifikasi diri adalah sebagai berikut:

\begin{tabular}{|c|c|c|}
\hline Pertanyaan & Jawaban & Nilai \\
\hline $\begin{array}{l}\text { Alasan menjual private content } \\
\text { dan harga yang ditawarkan. }\end{array}$ & $\begin{array}{l}\text { @yoursugarbabyxxx: "Awalnya iseng aja sih kak, tapi ternya- } \\
\text { ta jadi banyak pemasukan. Aku kan kalo transaksi suka lewat } \\
\text { OVO atauDANA, namakubisa disensor atau dipalsukan disana. } \\
\text { Tetap aman sih. Biasanya 50-600 ribu aja buat paketan. Paket } 1 \\
\text { foto doangharga cuma 50k, kaloyang ratusan ribuitu udah sama } \\
\text { video masturbasi. Kadang ada juga yang ngirim sampe sejuta } \\
\text { ataulebih, katanya sih karenabadankubagus jadi dikasihbonus." } \\
\text { @chloexxx: "Aku suka melihat orang-orang seakan tunduk } \\
\text { padaku dan kayak aku yang mengendalikan mereka. Jadi aku } \\
\text { tease untuk kepuasan pribadi aja sebenernya, bukan untuk } \\
\text { duit-duit amat. Aku juga suka dinilai sama mereka terutama } \\
\text { tentang bagian-bagian tertentu di tubuhku. Harga per konten } \\
\text { sih } 100-1 \text { juta. Udah termasuk video, rekaman suara, dan ada } \\
\text { bonus vcs (video call sex) juga. Tapi kalo ga mood, ya ga aku } \\
\text { jual, cuma posting-posting aja di twitter buat godain orang." } \\
\text { @guiltywhalesxxx: "Mending jual sendiri daripada di- } \\
\text { jual sama orang lain kan? Toh tubuh kita milik kita } \\
\text { sendiri, kita bebas mau melakukan apapun dengan tu- } \\
\text { buh kita, selama tidak berada di bawah tangan orang } \\
\text { lain. Aku ga mematok harga sih, biasanya customer-ku } \\
\text { udah tau sendiri, ngirim di OVO ratusan ribu sampe ju- } \\
\text { taan. Kadang aku buka BO sih, cuma kalo pengen, bu- } \\
\text { kan buat duit juga. Lagian itu kan kebutuhan biologis ya." } \\
\text { @awcabyyxxx: "Kebebasan berekspresi dan pengendalian } \\
\text { tubuh oleh diri sendiri aja sih menurutku, jadi ga ada kon- } \\
\text { trol siapapun yang mengendalikan tubuh, di samping se- } \\
\text { bagai pemasukan juga sih, biasanya } 100 \text { ribu sampe } 1 \text { jutaan } \\
\text { buat satu paket private content tergantung isinya mau apa." }\end{array}$ & Kuasa tubuh \\
\hline
\end{tabular}

Tabel 2. Self commodification sebagai perlawanan atas politisasi tubuh

Berdasarkan tabel 2, praktik memperjualbelikan "konten" adalah sebagai perlawanan atas politisasi tubuh dan sebagai penegasan kuasa tubuh. Namun, praktik jual-beli ini juga memiliki sisi lain yaitu penilaian dari konsumen atas tubuh content creator. Hal ini memperlihatkan adanya dualisme dari seorang content creator, yakni sebagai objek sekaligus sebagai subjek dan agen aktif dalam praktik ini. Penilaian dilakukan oleh pembeli setelah transaksi terjadi, kemudian pembeli menyampaikan semacam testimoni atas foto-foto vulgar yang diterimanya. Harga yang ditawarkan oleh content creator tersebut dimulai dari Rp.50.000 untuk beberapa foto pribadi tanpa sensor, sampai jutaan rupiah termasuk beberapa video. Selain itu, beberapa dari informan juga membuka booking online yang dikategorikan ke dalam prostitusi online. Namun, tidak semua informan melakukan itu karena terpaksa atau karena membutuhkan uang, melainkan karena kebutuhan biologis.

\section{Faktor-Faktor yang Menyebabkan Terjadi- nya Anti-politisasi dan Komodifikasi Tubuh}

Berdasarkan tabel 1, dapat dilihat bahwa penyebab munculnya propaganda self love di media sosial adalah adanya keinginan untuk melakukan apresiasi dan penerimaan diri sendiri beserta segala kekurangannya, dan berlepas diri 
dari berbagai pihak yang mengendalikan, mengatur dan menundukkan diri mereka. Hal ini juga perlawanan terhadap segala hukum yang ada, termasuk di dalamnya norma-norma yang dianggap memaksa untuk dipatuhi sekaligus simbol kebebasan dan kritik atas kejenuhan terhadap rutinitas politik dan agama yang seringkali ditampilkan di media sosial. Selain itu, faktor penyebab terjadinya anti-politisasi dan komodifikasi tubuh berdasarkan tabel 1 dan 2 dapat dirumuskan sebagai berikut:

\section{Kritik terhadap politisasi tubuh oleh negara}

Tubuh senantiasa berada dalam tekanan modernitas yang dikendalikan oleh kapitalisme dan politik. Tubuh menjadi titik sentral mesin produksi, promosi, distribusi, dan konsumsi kapitalis. Politisasi tubuh perempuan yang seringkali muncul dalam paradigma "cantik" yang ditampilkan oleh berbagai media menampilkan kritetia kecantikan tubuh perempuan yang harus berkulit putih, kurus, langsing, tinggi, mulus, dan sebagainya. Kriteria-kriteria tersebut seringkali menjadikan perempuan harus menahan dirinya dari segala hal yang dapat membuat tubuh mereka tidak sesuai dengan standar kecantikan yang ada. Perempuan seringkali merasa khawatir terhadap kenaikan berat badan, kulit berjerawat, stretchmarks, keriput, kulit menghitam, dan berbagai problem tubuh lain. Kekhawatiran ini diakomodasi oleh negara dengan menciptakan stigma-stigma cantik dan tidak cantik, serta menjadikan ketakutan-ketakutan tersebut sebagai sasaran utama dari konsumsi (Piliang, 2004). Stigma yang ada menciptakan berbagai kebutuhan terkait dengan pembentukan tubuh (body building) yang "ideal", misalnya dengan operasi plastik, fitness, perawatan wajah, dan lainlain yang dipromosikan melalui media massa. Fakta tersebut menggerakkan banyak orang yang sadar bahwa cantik itu tidak harus memenuhi segala standar yang ada, melainkan berasal dari dalam diri individu. Cantik tidak harus putih, langsing, atau berkulit mulus. Berbagai cara dilakukan untuk melawan stigma tersebut, salah satunya dengan memberitakan bebe- rapa perempuan sukses dalam pendidikan serta karirnya tanpa melihat kepada bentuk dan warna tubuhnya, sehingga saat ini ramai istilah "kecerdasan adalah cantik dari sisi yang lain", "cantik itu pintar", dan sebagainya. Di media sosial, kritik dan perlawanan terhadap politisasi tersebut dimunculkan dalam berbagai foto diri dan menampilkan kekurangan-kekurangan yang ada pada tubuh, seperti perut berlipat-lipat, stretchmarks, jerawat, kulit hitam, dan sebagainya.

Selain sebagai perlawanan terhadap standar dan normalisasi yang ada, self-commodification juga menunjukkan kekuatan perempuan atas laki-laki, yaitu dengan mendominasi dan mengendalikan laki-laki melalui hasrat seksual. Di negara yang patriarkis, laki-laki selalu dianggap sebagai pihak yang dominan, dan mensubordinasi perempuan. Perempuan menghadapi ketidakmungkinan untuk keluar dari sistem tersebut, sehingga mereka melakukan perlawanan dalam bentuk lain yaitu menunjukkan kuasanya atas laki-laki dengan mengeksploitasi seksualitas dan mengendalikan laki-laki (sebagai pemilik modal) untuk dapat memenuhi kebutuhannya.

\section{Bias negative positivity dan kurangnya kontrol diri}

Di sisi lain, terjadi salah kaprah wacana self love yang berujung pada ko

modifikasi diri sendiri atau self commodification, yakni meli- batkan diri pribadi dengan model hubungan pasar dengan praktik-praktik jual-beli foto-foto vulgar yang terjadi belakangan ini sebagai praktik "personal branding". Praktik ini bertujuan untuk menumbuhkan nama dan citra diri yang dimanipulasi untuk keuntungan ekonomi (Davis, 2003). Tubuh perempuan dijadikan sebagai alat produksi yang menjadi komoditi sesksual melalui eksplorasi berbagai potensi hasrat dan libidonya untuk dipertukarkan, sehingga menimbulkan stereotip atau bahkan menjerumuskan perempuan ke dalam tindakan-tindakan yang tidak senonoh yang dialamatkan kepada dirinya. 
Ketika perempuan tidak mampu mengontrol kuasa atas tubuhnya sendiri, hal ini menunjukkan kurangnya kontrol diri dari individu yang disebabkan oleh media sosial. Kontrol diri adalah kemampuan untuk membimbing, mengatur, dan mengarahkan perilaku yang dapat membawa ke arah yang positif dengan mengangkat potensi yang dapat dikembangkan dan digunakan, termasuk dalam menghadapi kondisi yang terdapat di lingkungan masyarakat.

Sesuatu yang negatif apabila dilakukan terus-menerus dan dipublikasikan kepada khalayak ramai cenderung dianggap sebagai sesuatu hal yang wajar dan tidak lagi bertolak-belakang dengan norma sosial. Di dalam memahami praktik self commodification, dapat disimpulkan bahwa ketiadaan atau lemahnya kontrol diri individu dapat berakibat fatal, terutama pada salah kaprah apresiasi diri atau mencintai diri sendiri melalui cara-cara yang justru bersifat destruktif, damaging, dan berbahaya. Mencintai dan mengapresiasi diri sendiri adalah sesuatu hal yang positif, namun memperlihatkan tubuh dalam ketelanjangan untuk menjadi komoditi ekonomi adalah negativity bias ${ }^{4}$.

\section{Gaya hidup}

Tubuh secara biologis dari ujung kepala hingga ujung kaki, beserta segala sistem yang bekerja di dalamnya memiliki kebutuhan-kebutuhan tertentu untuk dapat terus bergerak aktif dengan baik. Di dalam melangsungkan kehidupan sosialnya, tubuh tidak terlepas dari berbagai macam gaya hidup. Dorongan-dorongan untuk tampil di lingkungan sosial secara maksimal didukung dengan kemampuan finansial yang mumpuni, menjadikan pemilik tubuh memiliki gaya hidup tertentu, yang seringkali dipengaruhi oleh gaya hidup Barat atau Asia Timur (Korea dan Jepang). Hal ini menarik untuk dipelajari, terutama perempuan di media sosial yang dipengaruhi oleh berbagai acara K-drama atau film Jepang. Imbas dari gaya hidup yang terpengaruh oleh pengaruh luar adalah munculnya sikap konsumerisme. Gaya hidup konsumtif ini bagi sebagian orang meningkatkan semangat kerja untuk mencapai tujuannya. Namun, bagi sebagian lain terutama perempuan yang memiliki naluri eksibisionis dan narsistik, hal ini membuka peluang bagi mereka untuk memperjual-belikan private content yang tidak seharusnya menjadi konsumsi publik. Hal ini dibuktikan dengan ungkapan berikut:

"Dengan gue jual konten, gue bisa memenuhi kebutuhan gue yang mahal-mahal, bisa perawatan wajah, dan beli apartemen di $\mathrm{M}^{* * * * * * \text {, }}$ - (Wawancara virtual dengan @ Awcabyyxxx, 10 Mei 2020)

Gaya hidup seperti ini membuat perempuan menjadikan tubuhnya sebagai komoditi yang menghasilkan keuntungan pribadi yang menempatkan dirinya sebagai subjek sekaligus objek. Objektivikasi, dengan demikian, tidak selalu diakibatkan oleh peran laki-laki, namun juga oleh dirinya sendiri. Informan tidak merasa dirinya dieksploitasi, namun lebih dari itu, mereka menganggap apa yang dilakukannya adalah apresisiasi terhadap dirinya.

\section{Propaganda dan counter-attack negara dalam wacana self love}

Wacana self love dalam media sosial turut mengundang negara untuk campur tangan menghadapi fenomena ini. Negara saat ini dihadapkan dengan arena baru yang berkaitan dengan psikologis, sosial dan isu-isu legal yang dibawa oleh media sosial. Arus informasi yang terbuka, semakin canggih dan masif, mengakibatkan orang dapat terhubung dari berbagai belahan dunia dalam satu waktu. Perkembangan teknologi berdampak pada mudahnya akses informasi, termasuk pornografi yang seringkali tidak terkontrol melalui batasan usia. Beragam platform bahkan dengan terbuka menyediakan akses untuk menjelajahi pornografi di internet,

\footnotetext{
${ }^{4}$ Vaish et al (2008: hlm 383) mengungkapkan bahwa negativity bias atau bias negatif mengacu pada kecenderungan individu untuk mengambil dan menggunakan informasi yang negative jauh lebih banyak daripada informasi positif. Dalam tulisan ini negativity bias dalam komoditi pribadi merujuk pada hal yang bersifat negative namun dianggap sebagai sesuatu hal yang positif.
} 
termasuk menyediakan ruang berbagi dengan metode jual-beli seperti OnlyFans.com, Patreon. com, dan dipasarkan melalui Twitter.com. Platform-platform tersebut seringkali tidak terkontrol rentang usia penggunanya, sehingga konten pornografi dapat dinikmati oleh semua kalangan usia. Oleh karena itu, untuk tetap mendisiplinkan tubuh masyarakatnya, pemerintah telah mengatur regulasi tentang pornografi dengan mengeluarkan Undang-Undang mengenai para pelaku penyebar konten pornografi di media sosial yang diatur dalam Undang-Undang No. 44 Tahun 2008 Tentang Pornografi. Pada Pasal 4 Ayat (1) UU 44 Tahun 2008 mengatur larangan perbuatanmemproduksi, membuat,memperbanyak, menggandakan, menyebarluaskan, menyiarkan, mengimpor, mengekspor, menawarkan, memperjualbelikan, menyewakan, atau menyediakan pornografi yang secara eksplisit memuat: (a) persenggamaan, termasuk persenggamaan yang menyimpang; (b) kekerasan seksual; (c) masturbasi atau onani; (d) ketelanjangan atau tampilan yang mengesankan ketelanjangan; (e) alat kelamin; atau (f) pornografi anak. Selain itu, pengaturan mengenai hukuman bagi pelaku penyebar konten pornografi ini diatur di dalam Pasal 27 ayat (1) UU Nomor 11 tahun 2008 Tentang Informasi dan Transaksi Elektronik (UU ITE) yang berbunyi:

"Setiap orang dengan sengaja dan tanpa hak mendistribusikan dan/atau mentransmisikan dan/atau membuat dapat diaksesnya Informasi Elektronik dan/ atau Dokumen Elektronik yang memiliki muatan yang melanggar kesusilaan."

Pemerintah juga telah memberikan ancaman pidana terhadap para pelanggar, pelaku penyebaran konten pornografi tersebut yang diatur dalam Pasal 45 ayat (1) UU ITE, yaitu ancaman pidana penjara paling lama 6 (enam) tahun dan/atau denda paling banyak 1 (satu) milliar rupiah.

Di dalam berita yang dilansir BBC.com (2019) ${ }^{5}$, dijelaskan bahwa Kementerian Komunikasi dan Informatika (Kominfo) telah memberlakukan denda senilai ratusan juta rupiah kepada platform media sosial dan penyedia konten digital lainnya yang menampilkan pornografi, kekerasan, hingga propaganda terorisme. Denda yang dijatuhkan senilai Rp. 100 juta-Rp. 500 juta untuk setiap konten negatif yang ditemukan. Langkah ini dilakukan sebagai counter-attack negara terhadap kebebasan akses pornografi di platform-platform media sosial raksasa seperti Facebook, Twitter, Instagram, dan sebagainya.

Tubuh adalah penanda eksistensi manusia, yang menunjukkan kehadiran atas identitas seseorang. Tubuh tidak hanya terkait dengan entitas biologis yang dapat dikenali dari bentuk, warna kulit, dan sebagainya. Lebih dari itu, tubuh menjadi subjek yang memiliki kesadaran, rasio, pengalaman, dan pengetahuan yang dikenai dengan berbagai perangkat aturan norma dan nilai yang sejak lahir telah mendisiplinkan tubuh. Tubuh tidak hanya hadir dalam bentuk subjek, melainkan menjadi objek bagi kekuasaan atau otoritas yang bekerja di atasnya. Tubuh sebagai objek dimaknai bahwa tubuh dapat menjadi ranah eksploitatif dan berada pada posisi di bawah kekuasaan. Berdasarkan perspektif wacana kekuasaan Foucault, tubuh perempuan menjadi objek rezim penguasa untuk mengendalikan, menundukkan, mematuhkan dan menjinakkan tubuh untuk dapat dikontrol dan dikuasai. Pengendalian oleh otoritas yang berkuasa tidak dilakukan secara represif, melainkan melalui kontrol atau pengendalian dan normalisasi.

Di sisi lain, selain sebagai apresiasi diri dan penerimaan terhadap segala kekurangan yang ada pada diri sendiri, wacana self love juga dimanfaatkan sebagai ajang komodifikasi diri sendiri (self commodification) dengan menjual private content dengan rating harga puluhan ribu hingga jutaan rupiah dan membuka kesempatan untuk terjadi transaksi booking online (BO) yang mempertemukan penjual dan pembeli di ruang nyata. Wacana self love dengan menampilkan ketelanjangan dan menjual produk ketelanjangan menjadi sebuah kritik terhadap negara yang memiliki otoritas untuk melakukan disiplin tubuh. Wacana

\footnotetext{
${ }^{5}$ Berdasarkan informasi yang diperoleh dari https://www.bbc.com/indonesia/indonesia-50312826 diakses pada senin, 11 Mei 2020.
} 
ini menyampaikan gagasan bahwa tubuh adalah milik perorangan yang tidak dapat dikenai berbagai aturan yang membelenggu, dan bahwa si pemilik tubuh memiliki otoritas yang penuh atas tubuhnya, termasuk dalam hal memperjualbelikan konten yang memuat pornografi, atau bahkan dengan melakukan tindakan prostitusi online. Kritik terhadap negara melalui self-commodification ini juga memperlihatkan dominasi kaum perempuan untuk mengendalikan dan mempe- ngaruhi laki-laki sebagai representasi dari "negara".

Kajian yang telah dilakukan menunjukkan bahwa tidak selamanya tubuh perempuan dijadikan komoditas oleh pihak laki-laki, melainkan dapat pula perempuan itu secara sadar menjadikan tubuhnya sebagai komoditas ekonomi yang dapat dimanfaatkan untuk memenuhi berbagai kepentingan mereka melalui self-commodifcation. Hal ini dapat dikatakan sebagai bentuk salah kaprah atau blunder pemahaman mengenai self love, yang pada awalnya sebagai penerimaan diri atas kekurangan yang dimiliki, menjadi wacana baru dalam pemuasan pribadi atas kebutuhan-kebutuhan yang bersifat seksual. Berdasarkan fakta yang ada, memperlihatkan bahwa pada satu sisi, perempuan dapat terdorong untuk memaksimalkan potensi tubuhnya sebagai alat untuk menarik pasangan atau konsumen supaya dapat memenuhi kebutuhan mereka melalui pertukaran dengan fasilitas yang diinginkan. Namun, di sisi lain secara sadar mereka memahami bahwa tubuh mereka harus diserahkan kepada pemilik modal sebagai alat tukar. Hal yang perlu digarisbawahi di sini bahwa para perempuan itu melakukan dengan sadar dan menyadari bahwa tubuhnya dijadikan sebagai komoditas ekonomi untuk menghasilkan keuntungan bagi dirinya sendiri.

Pada dinamika sosial ekonomi, apabila perempuan dikatakan mandiri secara ekonomi, maka ia dapat mengaktualisasikan tubuhnya sebagai kekuatan, persepsi yang secara otonom memberi makna dan bentuk kepada objek di sekitarnya (Lie, 2005). Hal ini menunjukkan sebuah perlawanan terhadap ideologi patriar- ki, sehingga dengan beragam aturan yang ketat melalui normalisasi yang diciptakan oleh negara untuk menundukkan perempuan, mengakibatkan terjadinya perlawanan sebagai akibat dari ketidakmungkinan keluar dari struktur kuasa. Di sisi lain, hal tersebut dilakukan sebagai penegasan dan perlawanan sebagai penentuan otonomi tubuh mereka sendiri, sebagai bentuk antipolitisasi tubuh. Para perempuan itu memiliki hak penuh atas tubuhnya sendiri meskipun dengan cara memanfaatkan tubuhnya keluar dari norma dan aturan yang membelenggu. Di sinilah letak dinamika wacana self-love di media sosial yang membuka ruang-ruang untuk praktik-praktik ilegal namun dinormalisasi dan dianggap sesuatu yang lumrah terjadi terutama di media sosial. Pemblokiran berbagai situs pornografi dan penutupan tempat-tempat prostitusi tidak menjawab masalah ini, karena permasalahan sesungguhnya yang berada di akar adalah keinginan untuk melawan praktik-praktik propaganda pemerintah dalam merespon berbagai dinamika yang terjadi di masyarakat.

\section{Simpulan}

Praktik anti politisasi atas tubuh perempuan merupakan sebuah bentuk penegasan perempuan terhadap otoritas tubuhnya sendiri sebagai perlawanan atas politik disiplin tubuh yang dilakukan oleh negara. Namun, praktik ini seringkali disalahpahami sebagai upaya komodifikasi tubuh sendiri (self-commodification) melalui berbagai platform media sosial untuk mempertukarkan ketelanjangan dengan komoditas ekonomi yang bernilai tinggi. Hal ini membuat perempuan menjadikan tubuhnya sebagai komoditi yang menghasilkan keuntungan pribadi yang menempatkan dirinya sebagai subjek sekaligus objek. Di dalam hal ini, objektifikasi tidak selalu diakibatkan oleh peran laki-laki, namun juga oleh perempuan sendiri. Faktor-faktor penyebab terjadinya self-commodification ini adalah kritik terhadap politisasi tubuh oleh negara, yakni dengan "melanggar" sejumlah norma sosial yang diterapkan di masyarakat, dan penegasan otoritas penuh terhadap tubuh, dan sebagai kekuatan bah- 
wa mereka dapat menaklukkan laki-laki dengan tubuhnya. Selain itu, adanya negativity bias dan kurangya kontrol diri membuat perempuan tidak lagi mempertimbangkan nurani dan pemikiran yang sehat untuk melakukan jual-beli tubuh sendiri. Praktik ini juga didukung dengan keinginan untuk pemenuhan gaya hidup yang tinggi. Fenomena ini memperlihatkan bahwa di satu sisi, perempuan-perempuan tersebut ingin melakukan perlawanan atas politisasi yang terjadi, namun di saat yang bersamaan si pemilik tubuh juga mengobjektifikasi dirinya sendiri. Dengan demikian, perempuan menjadi agen aktif yang dalam kasus ini turut serta dalam proses objektifikasi tas dirinya sendiri.

\section{Daftar Pustaka}

Alyusi, S. D. (2017). Media Sosial: Interaksi, Identitas, dan Modal Sosial. Jakarta: Jakarta Kencana Prenadamedia Group.

Association of Progressive Communication. (2016). Feminist Principle of the Internet. Dikutip November 20, 2020, dari https:// www.apc.org/en/pubs/feminist-principles-internet-version-20

Atkinson, M. L. (2020). Gender and Policy Agendas in the Post-War House. Policy Stu-dies Journal, 48(1), 133-156.

Barker, C. (2005). Cultural Studies (Nurhadi (Penerjemah), Ed.). Yogyakarta: Kreasi Wacana.

BBC.Com. (2019). Konten Pornografi dan Terorisme di Platform Media Sosial, Pemerintah Indonesia Akan Terapkan Denda "Hingga 500 Juta." Dikutip dari https://www.bbc. com/indonesia/indonesia-50312826

Brook, J. (2012). Resisting the Virtual Life: The Culture and Politics of Information. Michigan: City Lights Publisher.

Coleman, J. S. (1986). Social Theory, Social Research, and a Theory of Action. American Journal of Sociology, 91(6), 1309-1335.

Davis, J. E. (2003). The Commodification of Self. Dikutip dari The Hedgehog Review Critical Reflections on Contemporary Culture website: https://hedgehogreview.com/issues/ the-commodification-of-everything/articles/ the-commodification-of-self\#: :text=A second meaning of self,we manipulate for economic gain.

Dzulkarnain, I. (2015). Kuasa Tubuh Atas Perempuan: Tela'ah Kritis terhadap Gerakan Sosial Gender Oleh: Prosiding Seminar Nasional
Gender And Development. Puslit Gender dan Kependudukan LPPM UTM.

Foucault, M. (1995). Discipline and Punish. Vintage Books.

Giddens, A. (1985). The Nation - State and Violence: Volume Two of a Contemporary Critique of Historical Materialism. Cambridge: Polity Press.

Harahap, M. I. (2011). Melempar seperti Perempuan: Renungan Aquarini tentang Politik Tubuh. Gatra.Com. Dikutip dari https://www. gatra.com/detail/news/412232//melempar-seperti-perempuan-renungan-aquarini-tentang-politik-tubuh.

Hardiyanto, P. S. (1997). Michael Foucault Disiplin Tubuh Bengkel Individu Modern. Yogyakarta: LKIS.

Keller, J. E. (2020). The sonic intra-face of a noisy feminist social kitchen. Journal of Social Sciences, 8(9), 245.

Khoshaba, D. (2012). A Seven-Step Prescription for Self Love. Dikutip dari Psychology Today website: https://www.psychologytoday. com/us/blog/get-hardy/201203/seven-stepprescription-self-love

Lianawati, E. (2020). Ada Serigala Betina dalam Diri Setiap Perempuan: Psikologi Feminis untuk Meretas Patriarki. Yogyakarta: Buku Mojok Group.

Lie, S. (2005). Pembebasan Tubuh Perempuan: Gugatan Etis Simone de Beauvoir terhadap Budaya Patriarki. Jakarta: Grasindo.

Marcuse, H. (1996). Eros and Civilization: A Phylosophical Inquiry ino Freud. Boston: Beacon Press.

Mark, A. (2013). Public Service Media Utilities: Rethinking Search Engines and Social Networking as Public Goods. Media International Australia, 146(1), 123-132.

Marwick, A. E. (2015). Instafame: Luxury Selfies in The Attention Economy. Public Culture, 27(1), 137-160.

Middleweek, B. (2020). Pussy Power Not Pity Porn: Embodied protest in the \#FacesOfProstitution Twitter Network. Journal of Sexualities, 23(3), 342-360.

Naezer, M. (2020). Sexy Selves: Girls, Selfies and The Performance of Intersectional Identities. European Journal of Women's Studies, 27(1), 41-56.

Nagarajan, C. (2016). What Does a Feminist Internet Look Like? Dikutip dari The Guardian, https://www.theguardian.com/uk/commentisfree/2016/sep/12/feminist-internet-em- 
powering-online-harrasment.

Ott, K. (2018). Social Media and Feminist Values: Aligned or Maligned? Frontiers: A Journal of Women Studies, 39(1), 93-111.

Owen. (2018). The Past Decade and Future of Political Media: The Ascendance of Social Media. In Towards a New Enlightenment? A Transcendent Decade. OpenMind.

Piliang, Y. A. (2004). Hiper-realitas Kebudayaan. Yogyakarta: LKiS.

Raditya, A. (2014). Sosiologi Tubuh. Yogyakarta: Kaukaba Dipantara.

Saptandari, P. (2013). Beberapa Pemikiran tentang Perempuan dalam Tubuh dan Eksistensi. Biokultural, 2(1), 53-71.

Shinta, N. (2017). Kapitalisasi Tubuh Perempuan (Sebuah Perspektif Ekofeminisme Islam. MUWAZAH, 9(1), 66-80.

Singer, J. D. (2018). Rethinking National Attribute Data: Reconstructing the Correlates of War Dataset on Material Capabilities of States. International Interactions, 14(2), 15-32.

Susilo, D., dan Kodir, A. (2016). Politik Tubuh Perempuan: Bumi, Kuasa, dan Perlawanan. Jurnal Politik, 1(2), 317-330.

Thompson, Z. (2016). Social Media and The Problem with Self Love. Dikutip dari Huffpost. com website: https://www.huffpost.com/entry/social-media-and-the-prob_b_10639846 